\title{
LA IDEA DE EUROPA EN LOS ENSAYOS de Claudio Magris y Jorge Semprún
}

\section{Gerard Torres Rabassa}

(Universitat de Barcelona)

\section{Europa como paradoja}

Sucede a menudo que el pensamiento, para seguir siendo posible y no renunciar a ser crítico, debe asumir que las paradojas, aporías y contradicciones que se encuentra no se podrán disolver mediante la confianza en una razón autónoma y segura de sí misma, sino que constituyen una parte esencial del pensar mismo, inevitablemente problemático y paradójico, atravesado por contradicciones, siempre liminar y abismático.

Jorge Semprún y Claudio Magris comparten, por encima de todo, la firme toma de consciencia de la problematicidad inherente de los conceptos y categorías que tratan de desarrollar. Desconfían siempre de las soluciones, plantean constantemente nuevas preguntas y sospechan de todas las respuestas; asumen que solo mediante una elaboración crítica de la ambivalencia, de la problematicidad y de la prosa del mundo será posible pensar la realidad sin traicionarla o manipularla ideológicamente, evitando adaptar la infinitud inefable de sus contradicciones a la falsa sistematicidad de todo pensamiento que se pretenda verdadero. En palabras del propio Magris, «el pensamiento se sitúa de la parte de Sancho Panza (...). La filosofía debe detenerse en la diferencia entre los ideales y las cosas, en la frustrada correspondencia entre la universalidad postulada por la idea y la miseria de lo real que lo desmiente» (1982:99).

Pero esta definición del pensamiento como escritura irónica y consciente de su falibilidad, ¿significa una renuncia a alcanzar cualquier forma de saber? ¿Implica igualar todos los discursos y despojar de capacidad crítica al sujeto, que ya no puede distinguir ni elegir 
posiciones en un magma indefinido en el que todo vale? Más bien todo lo contrario: la célebre formulación «Si Dios ha muerto, todo está permitido» que Dostoievksi puso en boca de Ivan Karamazov recibe un severo mentís en el proyecto escritural y literario de Magris y Semprún. Reconocer las aporías y paradojas que pueblan el mundo, irresolubles y constitutivas de la actividad humana, no significa ceder un solo paso ante el relativismo promulgado por algunas configuraciones de la posmodernidad. Antes que la sentencia despótica de Ivan Karamazov, Semprún y —especialmente- Magris prosiguen el camino iniciado por Nietzsche, para quien la muerte de dios no solo no implicaba el fin del pensamiento, sino que abría la posibilidad penosa y agónica, pero existente- de su sublimación. Recordemos las líneas que siguen a la famosa muerte de Dios de La gaya ciencia:

\footnotetext{
¿Quién nos limpiará de esa sangre? ¿Con qué agua podremos purificarnos? ¿Qué explicaciones, qué ritos sagrados nos veremos obligados a inventar? ¿La grandeza de este acto no es acaso demasiado grande para nosotros? ¿No nos vemos forzados a convertirnos a nosotros mismos en dioses, para parecer al menos dignos de los dioses? No hubo jamás una acción más grandiosa; y los que nazcan después de nosotros pertenecerán, por causa de aquella acción, a una historia más sublime de lo que lo haya sido jamás historia alguna. (1987:125).
}

Nietzsche esboza la posibilidad de sublimación de la historia por el pensamiento en un mundo desencantado y abandonado por los dioses; y su formulación parece un certero epíteto capaz de rendir cuenta del esfuerzo intelectual, responsable y antidogmático, desarrollado por Magris y Semprún.

¿En qué sentido habla Magris de un pensamiento que «se pone de la parte de Sancho Panza»? Piensa, el triestino, en una filosofía de tintes adornianos «atenta a los detalles mezquinos e insignificantes (...) para salvar los particulares y los fragmentos, y por tanto la vida, de cualquier falsa y monumental totalidad» (Magris, 1982:100-101). Pero a diferencia de Adorno, que transforma su permanente oscilación entre opuestos en un corsé repetitivo y previsible (1982:103), «el pensamiento que se coloca de la parte de Sancho Panza debería corregir, con ironía, también el pathos de aquella melancolía y de aquella resignación» (1982:104). La tensión dialéctica entre opuestos, correlato de la imposibilidad de encerrar el mundo y la vida en una definición monológica, debe preservarse ante todo dogmatismo. 
La ejemplaridad de Sancho Panza radica en que, a pesar de haber atestiguado que los ideales novelescos no se hallan materializados en el mundo, decide redefinir la utopía y proponer a don Quijote que se vayan al campo a vivir una ficción pastoril (Cervantes, 2001:1219). De este modo, mantiene viva la tensión entre utopía y desencanto, dos polos fundamentales de la modernidad que solo conjugados retienen su valor y que desempeñan, como es sabido, un papel clave en el pensamiento de Magris.

En un texto de elogio del escritor húngaro György Konrád, Semprún escribe: «habría que saber que las cosas no tienen remedio y, sin embargo, se debería estar dispuesto a cambiarlas» (2006:94). Imposible encontrar una forma más precisa de definir la necesaria tensión dinámica y dialéctica entre contrarios, presidida por el binomio dialógico utopía-desencanto, que tematiza Claudio Magris a lo largo de toda su obra. Semprún sabía, como Magris, que el pensamiento está del lado de Sancho Panza. Que no existe reflexión que no arranque de la curiosidad, de la ignorancia, de una voluntad de saber que es consciente de que no podrá agotar su objeto de conocimiento:

\footnotetext{
No hay reflexión teórica digna de ese nombre que no arranque del asombro, de la duda, de la perplejidad. Un pensamiento afincado en la certeza absoluta de sus propios postulados o puntos de partida no sería tal, en verdad. Solo sería un discurso monolítico, dogmático monólogo (Semprún, 2006:39).
}

Semprún y Magris interpretan el mundo y la historia con la humildad epistemológica del ensayista, conjugan curiosidad y responsabilidad, conscientes de que el conocimiento que podamos adquirir se verá siempre rebasado por nuestra ignorancia respecto al mundo, la vida, la historia y la cultura. En este sentido, es significativo que escojan habitualmente el género ensayístico para esbozar sus acercamientos a la idea de Europa, puesto que «el carácter del ensayo es irónico, lo cual significa (...) que la propia forma ensayo, su ser un ensayo, es un destino irónico en relación con las grandes cuestiones de la vida» (Said, 2008:76).

Asumir la condición irónica del pensamiento significa reconocer que el lugar que ocupa el hombre en la tierra es en sí mismo una encrucijada de la que no se puede salir, porque no existe el camino recto, ni el conocimiento pleno ni la verdad inquebrantable. Hace falta asumir 
la propia falibilidad y aceptar las contradicciones que constituyen el sustento de la vida misma. Han caído los ídolos, se han desterrado los dioses, se han desmitificado los mitos y la historia ha descendido a los infiernos. Siempre que el sujeto intente conocer desenredando los entuertos que pueblan la realidad, desactivando sus contradicciones o reprimiendo su forma de ser problemática, devendrá en una imposición monológica de la propia estructura conceptual que silenciará la heterogeneidad polifónica del mundo y nos impedirá hacerlo legible. A cualquier forma de imposición monológica responden Magris y Semprún con una escritura irónica, que se sabe imperfecta y que adopta a menudo la forma del ensayo para ensayar el conocimiento a la manera de Montaigne:

\footnotetext{
Desparramando aquí una frase, allá otra, como partes separadas del conjunto, desviadas, sin designio ni plan, no estoy obligado a ser perfecto, ni a concentrarme en una sola materia, varío cuando bien me place, entregándome a la duda y a la incertidumbre, y a mi manera habitual que es la ignorancia (Montaigne, 1962, v. I: 303-305).
}

Magris y Semprún tienen mucho en común: su gran conocimiento de la cultura germánica y judía; su capacidad de apreciar el valor de lo individual frente a la homogeneización, y al mismo tiempo lo compartido frente a la reivindiación mitómana de la diferencia; su europeísmo irrenunciable pero consciente de sus problemas e imposibilidades; su apuesta por una literatura consagrada a la historia, pero consciente a la vez de que el escritor está comprometido, ante todo, con el lenguaje y con su escritura; su cultivo de una textura literaria ensayística y narrativa a la vez, que explica la historia mediante la ficción y ficciona la escritura a partir de la historia; su resistencia ante toda monología y su voluntad de desmitificar todos los ídolos... Pero lo que une más íntimamente a Magris y a Semprún es que desarrollan un pensamiento problemático, sabedor de su eterna provisionalidad, consciente de que la contradicción no es lo opuesto del conocimiento sino aquello que le permite existir sin devenir totalitario. Su titánico esfuerzo se proyecta hacia la necesidad de seguir contando con la razón en un momento histórico en que se la contempla con absoluto descrédito; de seguir pensando los valores cuando ya nadie parece ser capaz de definirlos ni legitimarlos; de conjugar utopía y desencanto con el fin de elaborar una lectura del pasado y del presente capaz de resguardar a los hombres de la violencia en 
que la historia se hunde cíclicamente. Semprún y Magris desarrollan una definición irónica de la identidad, que va de la mano de una reflexión constante sobre el sujeto y su pertenencia a una realidad que lo transciende, pero a la que no se puede entregar con la vehemencia del mitómano. Y el decurso de todos estos pensamientos transcurre sobre el fondo de la historia y el presente de Europa, en la cual merece la pena seguir creyendo por su potencial capacidad — promesa quizás frustrada, pero siempre renovada — de unir supranacionalmente las culturas respetando aquello que tienen de individual. Europa, como promesa de unión de lo diverso, deviene un proyecto soñado al que jamás estarán dispuestos a renunciar, aunque se evidencie su condición problemática y eternamente inconclusa.

Europa: ¿un espacio geográfico? ¿Una ideología? ¿Un sistema de valores? ¿Una unión económica? ¿Una idea? Hallando un punto medio problemático entre la utopía y el desencanto, tanto Magris como Semprún nos recuerdan que no podemos dar por sentado que sepamos de qué hablamos cuando hablamos de «Europa». Su mirada crítica a la idea de Europa está curada de toda inocencia, pero tampoco cede ante la tentación de un desencanto escéptico. Como ha escrito Szavai, Europa encarna un «mouvement double et, en partie, contradictoire: d'un côté un effort qui vise l'unité, de l'autre le maintien et même, l'encouragement d'une variété qui est celle des cultures, et surtout des langues» (2005:9). Esta definición del proyecto europeo como contradicción constituye no solo un acierto, sino el punto de partida inexcusable de toda reflexión sobre Europa, su identidad simbólica y su capacidad política de estructurar formas de vida. También Marc Fumaroli ha hablado de «le paradoxe d'une Europe de fait», paradoja que «nous expose à perdre nos repères nationaux avant même d'avoir trouvé des repères continentaux» (2000: 8). Solo partiendo de la contradicción y asumiendo la problematicidad que le es inherente será posible pensar Europa sin caer en dogmatismos ni simplificaciones, ya sean en una dirección o en otra. Es necesario reconocer la naturaleza paradójica de esa «mirada desde lo alto, que abarca la diversidad del mundo en su unidad aunque sin reprimirlas» (Magris, 1982:22).

Semprún vivió en primera persona la revelación de Europa como paradoja, pues fue en el campo de concentración de Buchenwald donde por primera vez percibió la necesidad de pensar en esa entidad —Europa — problemática y redentora, utopía disuelta, promesa en ruinas. Ubicado en el Ettersberg, entre los campos de hayas a los que Goethe y Eckermann tenían por 
costumbre ir a pasear, Buchenwald fue un lugar de sublimación de la barbarie nacionalsocialista. Europa había sido capaz de engendrar la manifestación más pura del Mal Radical y asimismo su opuesto, el pensamiento humanista que halló su apogeo en la República de Weimar. Y además les hizo compartir, paradójicamente, irónicamente, una misma topografía: «el binomio geográfico Weimar-Buchenwald» (Semprún, 2006:156), que deviene un lugar privilegiado para pensar Europa desde la complejidad de su legado histórico.

Gracias a sus conversaciones con Henri Maspero, Maurice Halbwachs y otros presos, Semprún comprendió la necesidad de pensar Europa y de indagar en la consciencia europea. Pero estas conversaciones tuvieron lugar en la pestilencia del Barracón 56 del campo de concentración de Buchenwald, en plena autodestrucción del proyecto civilizatorio europeo, hundido en la barbarie y consagrado a la producción de muerte a escala industrial. Halbwachs, Semprún, Maspero y los demás integrantes de aquellas conversaciones desarrolladas en el corazón de una Europa destruida podrían haber cedido al escepticismo, incluso al recelo, respecto a la idea misma de Europa. Así le sucedió a Edgar Morin, como él mismo confiesa: «Durante mucho tiempo fui antieuropeo (...). La guerra era mundial (...). La que debía liberarse y federarse era la humanidad. Toda idea europea me parecía estrecha y mezquina» (Morin, 1998:11-12). Pero Semprún se inclinó por una actitud contraria y asumió la necesidad de seguir pensando Europa para tratar de reconstruirla desde sus despojos. Se trataba de reconstruir Europa no a pesar de los totalitarismos a los que se vio abocada, sino a partir de ellos y en contra de ellos. Frente a la gran dificultad de definir positivamente Europa, de otorgarle un contenido ontológico o una esencialidad propia, Semprún la piensa negativamente y de este modo le atribuye una identidad político-cultural que se define en oposición a los totalitarismos nacionalsocialista y estalinista. Como ha escrito Josep Ramoneda, «el gran mite fundador d'Europa ha estat el tabú de la guerra civil»(2005:80).

Magris y Semprún comparten, pues, una concepción de la identidad europea definida en contra de las guerras entre europeos y afincada en el poder redentor de la memoria.

\section{Europa, entre la utopía y el desencanto}

En su Introducción a ¿Una gran ilusión? Un ensayo sobre Europa Tony Judt reconoce su escepticismo ante la posibilidad de que algún día podamos ver una Europa unida. Se define, 
pues, como «europesimista» (2013:10); pero al mismo tiempo confiesa ser un europeo entusiasta, puesto que creer en Europa nos permite — como supo ver Jorge Semprún— dejar atrás las guerras que han empañado el pasado reciente del continente (2013:11). Esta ambivalente declaración de principios nos podría hacer pensar que Judt se ubica en el justo medio entre utopía y desencanto que - como veremos - es necesario para pensar críticamente el problema de Europa. Pero lo cierto es que acaba anclándose en un desencanto que no se deja corregir por la utopía, y la visión de Europa que aporta es profundamente escéptica respecto al presente y al futuro de una posible identidad político-cultural europea.

Judt recuerda que la Comunidad Europea del Carbón y del Acero se fundó, en 1951, como materialización de las luchas y recelos existentes en la política internacional de las grandes potencias europeas, principalmente Francia y Alemania. Explica que Francia solo aceptó el pacto europeo porque necesitaba una Alemania poderosa (puesto que dependía económicamente de ella en muchos aspectos) pero, al mismo tiempo, que no constituyese una amenaza. Como escribió Jacques Delors, que acabaría siendo presidente de la Comisión Europea: «Crear Europa es una forma de recuperar ese margen de libertad necesario para una 'cierta idea de Francia'» (apud. Judt, 2013:24-25). La Unión Europea surgió como un accidente (2013:51), fue el fruto de un conjunto de intereses individuales por parte de Francia, Alemania y los países del Benelux. Y solo la prosperidad económica posibilitó su paulatino crecimiento en los años posteriores, en los que se fueron anexionando nuevos estados movidos por su propio interés particular.

Aunque afirma que cuestionar la naturaleza y los propósitos de Europa no significa ignorar sus méritos, Judt retoma incesantemente su interpretación de Europa como un conjunto inestable de intereses económicos que «es algo más que un concepto geográfico, pero no llega a ser una respuesta» (2013:152).

El texto, muy esclarecedor respecto a las tensiones internacionales que seguían existiendo después de la Segunda Guerra Mundial, presenta sin embargo algunos problemas. Principalmente, resultan problemáticas dos de sus argumentaciones basales: 1) el aserto de que todos los logros colectivos que ha alcanzado Europa son accidentales y solo posibles gracias a la prosperidad económica; y 2) la idea de que solo con el fin de legitimar su bienestar económico el pensamiento europeo «ha apelado a una especie de ética ontológica de comunidad política que se aplica en retrospectiva para exponer los beneficios conseguidos hasta entonces y justificar posteriores esfuerzos unificadores» (Judt, 2013:34). 
¿Acaso podemos afirmar que solo a partir de la segunda mitad del siglo XX, y con el mero fin de salvaguardar los logros económicos, surge un pensamiento que reflexiona en torno a la supranacionalidad europea? ¿No es la historia europea la historia de un proyecto supranacional autoconsciente, repleto, es cierto, de contradicciones, retrocesos e intereses nacionales, pero al mismo tiempo hecho de puntos de vista comunes y de acuerdos más o menos estables respecto a un modelo político democrático y una idea compartida de ciudadanía?

El historiador Josep Fontana también ha puesto de manifiesto que los intentos de definir Europa como algo más que una denominación geográfica surgieron como tentativas de constatar que los sujetos europeos eran aquellos que habían alcanzado la cima del progreso, la civilización y el bienestar económico (2005:65). Se pretendió legitimar, desde la historia, la excepcionalidad de las riquezas y del poder político acumulado por Europa, y se trató de establecer una fundamentación histórica de la Unión Europea, aunque la realidad de la historia contradice este ejercicio y resulta imposible sostener la idea de una alianza histórica permanente entre los países europeos.

Igual que Tony Judt, Fontana atribuye al origen de la Unión europea un conjunto de razones económicas y políticas esencialmente nacionalistas. Pero el estudio de esos intereses económicos y materiales no impide a Fontana seguir tomando en cuenta que sí existen unos rasgos — más o menos estables-_ constituyentes de la identidad europea:

\footnotetext{
Els grans trets que han permès de forjar aquesta cultura i elaborar a partir d'ella uns signes d’identitat, són, per una banda, la tradició de les lluites contra el despotisme dels imperis (...) que conduiran al desenvolupament de sistemes de govern representatiu. I, per I'altra, l'elaboració d'una cultura racional i crítica (...). Aquesta doble tradició inspirarà entre nosaltres una lluita sostinguda per les Ilibertats individuals i els drets humans (2005:69).
}

En su libro escrito a cuatro manos junto a Dominique Villepin, El hombre europeo (2006), Jorge Semprún comparte este diagnóstico optimista de la identidad cultural y política europea y, de hecho, lo despliega hasta el extremo. Eleva la cultura europea al nivel de un sueño emancipador en vías de realizar su propio concepto histórico hasta la plenitud: «de todas las culturas del mundo, la europea es la única cultura de la razón (...) La razón es la que desempeña la función determinante en todas las cuestiones fundamentales del mundo de la vida (...). Pues 
bien, la autonomía de la cultura europea se basa en ese rasgo distintivo» (Semprún y Villepin, 2006:72). Como consecuencia, según Semprún es necesaria «la mundialización del espíritu europeo (...), la europeización del mundo» (2006:72), cuya viabilidad es avalada por el éxito obtenido por «la vía de la diplomacia, del diálogo, de la ejemplaridad, del contagio cultural de ideas que son fuerzas» (2006:72).

El hombre europeo nace de una encrucijada históricopolítica muy concreta, a saber: el rechazo en Francia, vía referéndum, de la Constitución europea en 2005. Es sin duda por ello que, en algunos pasajes, el tono del texto se acerca al panfleto político.

Lo cierto es que para Semprún, la idea de Europa siempre fue una promesa utópica que posibilitaba el regreso de la paz en un continente que a punto estuvo de provocar su propia autodestrucción. El redescubrimiento de Europa implicó para Semprún la posibilidad de seguir pensando la utopía: ante el desengaño causado por el fracaso histórico de la revolución marxista en su acepción leninista, Semprún otorga una centralidad cada vez mayor a la idea de Europa, garante del respeto a la pluralidad y al mismo tiempo de una unidad suprafronteriza basada en los valores democráticos. Sin embargo, nunca pierde de vista las ambigüedades del proyecto europeo y las zonas oscuras que ensombrecen sus luces, como el riesgo permanente de la regresión a la barbarie o la realidad de una población europea que sigue principalmente identificada con su Estado-nación. Ahora bien, será solamente en El hombre europeo donde dejará de lado las ambigüedades y contradicciones, definiendo Europa como «guía, como ejemplo, como el explorador que abre camino» (2006:234) y que se pone al servicio de toda la humanidad.

En este sentido, es oportuno recordar, como ha sostenido en diversos lugares Claudio Magris, que las nuevas voces que lleguen a Europa y nos puedan ayudar a construirla «podrán venir de cerca o de lejos, de Europa, que permanece como una maestra antigua y siempre nueva y quizá también de África o de China, de aquellos continentes del espíritu que tratan de llegar a ser modernos pero no de la misma manera, como nosotros y no como nosotros» (Magris, 1982:140). Es fundamental tener presente que la modernidad europea no constituye el fin de la historia al que acabarán llegando, tarde o temprano, todas las culturas civilizadas del mundo. La historia no ha terminado. Semprún es muy consciente de ello, y lo demuestra a lo largo de su producción novelesca y en los heterogéneos textos ensayísticos que recoge Pensar en 
Europa. Lo explicita repetidamente: la democracia liberal «es el sistema más apto para permitir el ejercicio colectivo de las libertades individuales y ciudadanas. Ello no representa el final de la historia, ciertamente. Muy al contrario, representa más bien la posibilidad de que se inicie la historia de la libertad y de la responsabilidad» (Semprún, 2006:235). Pero en su libro escrito junto a Villepin cede a cierto europeísmo apologético, no lo suficientemente problemático y sospechoso. Es como si la utopía se emancipara del desencanto y el discurso deviniera, en ese preciso momento, monológico'

La reflexión europea no puede prescindir de esa dialéctica irresoluble entre utopía y desencanto, que «antes que contraponerse, tienen que sostenerse y corregirse recíprocamente» (Magris, 1999:13). Entre el pesimismo economicista de Tony Judt y el excesivo triunfalismo que desprende, en algunos pasajes, El sujeto europeo, es necesario recordar que la historia es una «maraña de emancipación y regresión, tan a menudo unidas como las dos caras de la misma moneda» (1999:9), y sobre todo, que «el mundo no puede ser redimido de una vez por todas y cada generación tiene que empujar, como Sísifo, su propia piedra» (1999:11). El europeísmo de Magris, como también el de Semprún, surge de una lectura desencantada e irónica de la realidad, de la asunción de que la historia no ha terminado ni podrá hacerlo jamás, sino que se escribe día a día sin dejar nunca definitivamente atrás el abismo de la barbarie. Después de dos guerras mundiales y todo un siglo de conflictos y muerte, el pensamiento debe asentarse en la sospecha constante, en un mirar desencantado pero melancólicamente utópico. La amenaza del totalitarismo sigue vigente, se manifiesta en las gelatinosas ideologías débiles que promueve el capitalismo avanzado y en el poder disgregador de las comunicaciones, y, para Magris, la «forma de resistir a este totalitarismo es la que radica en la defensa de la memoria histórica» (1999:19).

A ello se consagra, precisamente, el proyecto literario desarrollado por Jorge Semprún: trata de presentizar el pasado de la barbarie para liberar a Europa del fantasma del totalitarismo.

1 En esta misma dirección, Ana García Díaz ha escrito: «la misma concepción eurocéntrica y resistente parece sustentar, en cierto modo, cierta falta de crítica con el presente y, más concretamente, con el proyecto político de la UE, y evita enfrentarse a posiciones más críticas del mismo» (2011: 60). Aunque podemos compartir esta postura respecto a algunos textos concretos de Semprún, lo cierto es que resulta impreciso hablar de un discurso unitario en toda su obra, que precisamente se caracteriza por cambiar constantemente de perspectiva. Lo que en ningún caso es válido es hacer extensible esta crítica a toda la obra de Semprún, especialmente a sus textos literarios y en concreto a La escritura o la vida, como lo hace García Díaz: «La escritura o la vida resignifica la experiencia totalitaria como una necesidad en el camino de progreso de la historia política y ontológica europea, y mantiene así sin cuestionar ciertos aspectos conflictivos del pensamiento sustentador de la experiencia de los campos» (íbid.: 61). Afirmar que Semprún entiende el totalitarismo como una «necesidad en el camino de progreso» es simplemente un falseamiento, e implica ignorar la infinidad de veces que somete a crítica la concepción dialéctica de la historia y la posibilidad misma de un progreso humano. Es cierto que Semprún celebra la implantación en España de la democracia parlamentaria, pero también lo es que advierte de la necesidad de corregir y «pagar algún día el justo precio» por la «amnesia colectiva voluntaria» (2006: 155) que se instauró durante la Transición, y que repite constantemente que la historia no tiene ni fin ni fines, que nunca alcanzaremos el fin de la historia. 
Pero es consciente de la problematicidad inherente a esta tarea, sabe que se embarca en un proyecto imposible, inacabable e inasumible. Semprún escribe con la intención de testimoniar, pero asume que el sujeto no puede aspirar a hacerse cargo literariamente de su experiencia sin transformarla: «No hay arte sin artificios. No hay memoria sin una estructuración artística del recordar» (Semprún, 1993: 88).

La más lúcida conjugación de utopía y desencanto desarrollada por Semprún radica en que asume que la literatura no puede explicar el pasado ( Se necesitarían horas, temporadas enteras, la eternidad del relato para poder dar cuenta de una forma aproximada» (1995: 25)), pero aun así no cesa nunca en el empeño de contar, y en contar siempre de otra forma, de una forma nueva que repite y supera, al mismo tiempo, todo lo dicho anteriormente. Su irrenunciable voluntad de testimoniar encarna una forma de utopía, pero su consciencia de la incapacidad de la escritura de presentizar la experiencia matiza desde el desencanto la intentio testimonial de su literatura.

Semprún es consciente de la crisis de la epistemología histórica y de la escritura biográfica, sabe que el sujeto de conocimiento transforma siempre el pasado desde su historicidad y opera una selección ideológica de algunos sucesos del pasado. Sabe que todo texto se estructura alrededor de artificios, por mucho que desee limitarse a contar el pasado: «Únicamente el artificio de un relato dominado conseguirá transmitir parcialmente la verdad del testimonio» (Semprún, 1995: 25). Así pues, trata de hacerse cargo de su experiencia pasada, pero es consciente de que para ello deberá buscar nuevas fórmulas literarias, es consciente de que el descrédito hacia la capacidad representativa de la escritura se manifestará inevitablemente en la dimensión formal de sus novelas. Por eso reconoce que: «A veces invento personajes. $\mathrm{O}$ en mis relatos les doy nombres ficticios, aunque ellos sean reales. Las razones (...) dependen siempre de necesidades de carácter narrativo, de la relación que hay que establecer entre lo verdadero y lo verosímil» (2001: 222). Autores como Céspedes Gallego (2012: 65-74) han visto la elíptica escritura sempruniana como una artimaña retórica que pretende esconder el papel de Kapo que supuestamente desempeñó en Buchenwald ${ }^{2}$. El lado más problemático o controvertido de la figura de Jorge Semprún también es enfatizado en la reciente biografía de Soledad Fox Maura (2016) y, en mucha menor medida, en la más antigua biografía de Augstein (2010). 
Las novelas de Semprún renuncian a la linealidad cronológica: «no hay nada tan irreal como el orden cronológico. Es una abstracción, una invención cultural» (Semprún, 1980: 131) y renuncian también a la ordenada pulcritud del realismo, al relato exhaustivo del testimonio, a la búsqueda de un sentido unitario que permita comprender el pasado y encerrarlo en una definición estable. Optan por la disgregación, por la concatenación de fragmentos memorísticos arbitrariamente superpuestos en una estructuración caótica que encuentra su centro de gravitación no en la homogeneidad de la trama, sino en la subjetividad de un narrador que resignifica sus experiencias desde el prisma subjetivo del presente de la escritura. El narrador no renuncia a la utopía de contar su experiencia, pero toma consciencia de la imposibilidad de trasladar al lector a un pasado extraviado: «La historia es una invención, e incluso una reinvención perpetua, siempre renovable, de la verdad» (Semprún, 1980: 410).

La epopeya narrativa de Semprún tiene mucho que ver con la de aquellos escritores europeos a los que tantas páginas ha dedicado Magris, cuya tematización nihilista del sinsentido de la vida deviene el núcleo mismo que irradia sentido a su existencia: «con distintas maneras y estilos vienen a decir que el sentido de la vida se ha perdido. Sienten la pérdida, la ausencia, el vacío de nuestra existencia pero el modo en que lo dicen representa el sentido de la propia vida» (Magris, en Larrocha, 2007:286). La escritura de Semprún y Magris asume la contradicción, el investimento irónico de un pensar marcado por la melancolía, pero que jamás se abandona al escepticismo relativista y prosigue incansablemente su búsqueda.

Magris y Semprún releen desde el desencanto la tradición europea, pero no renuncian a la utopía de seguir pensando Europa como unión en la diversidad. Revisitan desde el desencanto la noción de Weltliteratur que acuñó Goethe para intervenir en el devenir de Europa, pero no dejan de dialogar con la propuesta goethiana, interpretan los textos desde la supranacionalidad europea de la que forman parte $y$ desarrollan un proyecto literario que desprende una preocupación constante por la historia, el presente y el futuro de la cultura europea.

\section{Fronteras móviles, identidad irónica: el diálogo con la weltliteratur}

Para Jorge Semprún y Claudio Magris, Europa es un reto aún por realizarse, una idea en la que siguen confiando al mismo tiempo que perciben el peligro de su disolución y la degradación de sus valores. 
Después de la Segunda Guerra Mundial, el primer impedimento para pensar Europa era su partición en dos y la consecuente incomunicación del Este y el Oeste, que terminó por aceptarse con resignación desde la Europa democrática. Magris «pareció sentir la repentina ausencia de ese espacio (el Este) antes de llegar a la conclusión racional de que había sido borrado de la representación de Europa; y prefirió expresar su hallazgo a través de la literatura (...) para señalar que los europeos de la segunda mitad del siglo XX habían aprendido a convivir con una severa amputación» (Ridao, 2007:202). Para Magris, «esa Europa que sale destruida y amputada de la guerra, no se puede comprender sin la Mitteleuropa» (2007:202). En sus textos anteriores a 1989, y especialmente en El Danubio, trata de reponer esa parte amputada del continente europeo y toma nítidamente consciencia de que cualquier interrogación sobre el futuro de Europa pasa obligatoriamente por una reflexión sobre la Mitteleuropa y sobre Alemania.

De ello era plenamente consciente Jorge Semprún, que en 1986 lamentaba no poder visitar el árbol de Goethe (que los alemanes habían conservado en el recinto del campo de concentración de Buchenwald) porque se encontraba del otro lado del Muro, en el otro lado de la República Federal alemana, en la alteridad de una identidad europea en ruinas. Semprún no podía visitar el árbol donde Goethe inscribiera su nombre más de cien años antes debido a la división de Alemania, problema cuyo alcance afectaba de lleno a la idea misma de Europa: «el problema de la partición de Alemania (...) no es sólo un asunto interno: está en el centro de Europa, de su porvenir democrático»(Semprún, 2006:26). Y añadía: «la reunificación de Alemania ha de ser el fruto de un progreso decisivo de la democracia en Europa. En todas las Europas, la del Oeste, la del Sur la del Este» (2006:26). Como Magris, Semprún considera que la «Mitteleuropa es el eslabón determinante, este territorio donde se ha forjado durante siglos el destino cultural, por no decir político, del mundo» (2006:26) y fue en esa misma tradición alemana y mitteleuropea, la que había engendrado el monstruo del nazismo, donde halló la articulación de una respuesta intelectual que estuviera a la altura del horror que había testimoniado en Buchenwald.

Lejos de renegar de la cultura del país que había engendrado el totalitarismo, Semprún encontró en Husserl, Benjamin, Adorno, Marcuse, Canetti o Broch una suma de interlocutores válidos, en diálogo con los cuales era posible pensar la Europa de después de la barbarie. En los pensadores judíos que vivieron el exterminio desde el lado de las víctimas se encuentra la 
posibilidad de rescatar la «lucidez» y la «razón crítica» (2006:49) que Europa había perdido de vista. Se trata de un conjunto de voces «definitivamente desprovista de ilusiones: una lucidez herida por el sol cegador de la ilusión de verdades absolutas, ya rebasadas» (2006:49). Representan esa amarga lucidez, entre la utopía y el desencanto, surgida de las encrucijadas de Europa y de la melancolía mitteleuropea; esa lucidez que duele y que tan cercana le es, también, a Claudio Magris.

Magris y Semprún saben que toda producción artística, problema político o discusión sobre las formas de vida que tenga lugar en Europa estará marcada por su historicidad específica y por su origen nacional, pero al mismo tiempo su alcance se proyectará hasta todos los rincones del continente. No es posible pensar Europa sin tomar en cuenta las particularidades que la componen, pero tampoco podremos comprender ninguna particularidad si no la leemos en diálogo con la supranacionalidad europea de la que forma parte. Así, por ejemplo, el problema de la memoria histórica afecta a Alemania en tanto identidad nacional, pero a su vez «el problema del pueblo alemán con su memoria histórica nos concierne a todos los europeos más que directamente» (Semprún, 2006:155). El futuro de Europa solo se podrá construir si se interpretan dialécticamente los diferentes totalitarismos que tuvieron lugar, tomando en cuenta lo que cada uno de ellos tiene de específico pero sin aislarlo del contexto europeo al que efectivamente pertenece. No es posible pensar en una Europa constituida por una mera suma de identidades replegadas sobre sí mismas, por un conjunto de memorias nacionales aisladas y superpuestas.

Aquel domingo (1980) responde al propósito de avanzar, desde la ficción, en esa dirección. Su mayor ambición es poner en común las diversas memorias nacionales europeas y construir un acervo memorístico compartido en el que tengan cabida todos los horrores contra los cuales debe definirse la Europa del futuro:

\footnotetext{
Cuando leí Un día en la vida de Iván Denísovich (...) sabía que tendría que revivir mi experiencia de Buchenwald, hora tras hora, con la desesperada certidumbre de la existencia de los campos rusos, del Gulag de Stalin (...) Con la luz cegadora de los reflectores de la Kolyma iluminando mi memoria (1980:441).
} 
En 2005, en Weimar, Semprún expresó de nuevo esta idea fundamental:

\footnotetext{
La reciente adhesión de diez nuevos países del centro y del este de Europa — de la otra Europa, cautiva del totalitarismo soviético — no será culturalmente, existencialmente, efectiva, hasta que no hayamos repartido y compartido nuestras memorias. Esperemos que en la próxima conmemoración decenal, en 2015, hayamos incorporado a nuestra memoria europea colectiva la experiencia del gulag. Esperemos que junto a los libros de Primo Levi, Imre Kertesz o David Rousset, hayamos colocado los Relatos de Kolyma de Varlam Chalamov (Semprún, 2006:322).
}

La lógica transfronteriza de la dialéctica entre lo nacional y lo supranacional se instaura en el pensamiento de Semprún como una certeza que es asumida con total naturalidad y constancia. Así, por ejemplo, se pregunta: «¿cómo puede situarse la obra de Schelling - o de Kant, o de Fichte, o de Heine, o de Herder, por no citar más que a unos pocos entre los más importantesocultando las relaciones de la Alemania de la época con la Francia revolucionaria?» (2006:6869). De forma análoga a Claudio Magris, Semprún practica un comparatismo que va más allá de la repetición de tópicos encorsetados («stéréotypes consomés», para Fumaroli (2000: 7))³ y es consciente, como ya lo había sido Goethe, del importante papel que desempeñan las literaturas nacionales y las relaciones entre naciones en la construcción de una identidad europea. No se trata de repetir, como un mantra estéril, que somos todos cosmopolitas y que nuestra verdadera patria es el mundo entero. Es necesario repensar críticamente la idea de frontera y comprender que no es cuestión de interpretar las fronteras como barreras o bien ignorar su existencia, sino que, más allá de esta dicotomía, ha devenido urgente articular un pensamiento transfonterizo que parta precisamente de una problematización crítica y compleja del concepto de frontera. Las fronteras existen, y sus efectos rebasan el ámbito de lo geográfico y de lo político. No podemos ignorarlas, pero tampoco dejarnos encerrar dentro de ellas: «la frontera es doble, ambigua: en unas ocasiones es un puente para encontrar al otro y en otras una barrera para rechazarlo» (Magris, 1999:56). Por una parte «toda frontera tiene que ver con la inseguridad y con la necesidad de seguridad (...), sin ella no hay identidad» (1999:63). Pero, por otra parte, «deberíamos ser capaces de estar siempre del otro lado» (1999:79).

Como es sabido, en la base del pensamiento de Magris sobre la noción de frontera se halla lo que a menudo se ha llamado su triestinidad. Ciudad fronteriza geográfica, política y

\footnotetext{
3 En este sentido, Magris ha advertido que la «retórica de frontera, la que consiste en querer negar a toda costa cualquier frontera, en ponerse siempre del otro lado (...) corre el riesgo de convertirse en una fórmula estereotipada, una cómoda coartada literaria» (1999: 65).
} 
simbólicamente, en Trieste se tiene la sensación de vivir en la frontera, de ser incluso frontera (Magris, 1999:58). Ciudad que se hace cargo de un legado histórico y cultural profundamente complejo, plural y disgregado, Trieste «se encuentra en un 'collage' en el que nada se ha transferido en el pasado ni ninguna herida ha cicatrizado en el tiempo, en el que todo es presente, abierto y acerbo, en el que todo coexiste y es continuo» (Magris, 1982:374). En este «no tiempo» triestino, «ocaso de la vieja Europa» (1999:376), es donde Magris descubrió un lugar particular que «condensa la imagen determinante del mundo» (1999:370). Y esta idea de la contención de lo universal en lo particular ya no la abandonará nunca, sino que resulta decisiva en su concepción de las dos grandes tareas a las que ha dedicado toda su vida por igual: la escritura y la lectura.

Claudio Magris y Jorge Semprún comparten un mismo intento de pensar la complejidad de Europa sin rehuir el problema de la posición nacional e histórica que ellos mismos ocupan dentro de ella. En este esfuerzo, se erigen como continuadores de la noción de Weltlitertur que desarrolló Goethe en los últimos años de su vida. En el caso de Semprún, también encuentra en Marx un precedente del pensamiento comparatista y transnacional en el que se inscribe. En 1848, apenas dos décadas después de que Goethe planteara la necesidad de la Weltiteratur, el Manifiesto del Partido Comunista afirmaba que «la estrechez y cortedad de miras nacionales se van haciendo imposibles con el tiempo y, a partir de las diferentes literaturas nacionales y locales, va configurándose una literatura universal» (Marx, apud. Semprún, 2006:208).

Marx, Goethe y Husserl (concretamente la conferencia que pronunció en Viena en 1935) forman el triángulo crítico en diálogo con el cual desarrolla Semprún su pensamiento sobre Europa. Pero la figura de Goethe toma una centralidad especial, sin duda debido a su relación evidente con Buchenwald, lugar que Semprún siempre sintió como el origen de su formación humana e intelectual, como topografía fundacional de la construcción de una identidad posible. La voluntad weltliteraria de la obra de Semprún es incuestionable, y deviene manifiesta cuando afirma que:

\footnotetext{
mi patria no es la lengua, ni la española ni la francesa: mi patria es el lenguaje. O sea, un espacio de comunicación social, de invención lingüística; una posibilidad de representación del universo, de modificarlo también, aunque sea mínima o marginalmente, por el lenguaje mismo (Semprún, 2006:146).
} 
Para que sea posible construir una cultura supranacional europea, son fundamentales las aportaciones individuales de cada tradición literaria que se comprometan por encima de todo con el propio lenguaje, con la literatura, con la escritura, más allá de sus determinaciones históricas, lingüísticas y nacionales concretas. No es cuestión de ignorar la realidad de una Europa heterogénea y plural, sino de superar la diversidad para recalar en una unidad literaria compartida. Viviré con su nombre, morirá con el mío (2001) es posiblemente la obra de Semprún que más nítidamente muestra la existencia de una unidad literaria supranacional que no solo existe y es reconocible, sino que proporciona al narrador la posibilidad de refugiarse en ella para hacer más soportable, más humano, el horror que baña el día a día del campo. Es, por lo tanto, una segunda identidad posible del sujeto europeo, una segunda naturaleza que transciende la estrechez de miras de toda identidad cerrada, sólida e identificada únicamente con su realidad nacional. Rimbaud, Valèry y Girardoux, pero también César Vallejo, Cernuda y García Lorca, como Faulkner, como Goethe, como Schelling o Kant, incluso Maiakowsky... todos ellos conforman un entramado literario supranacional que hace posible, en el campo, la única forma de «engañar la angustia pegajosa de la promiscuidad perpetua: el recitado poético» (Semprún, 2001:212)

Después de ser señalado como extranjero invasor e indeseable por una panadera parisina que detecta su acento español (Semprún, 1998:59), el narrador de Adieu, vive clarté... (1998) no decide irse en busca de otra patria que lo reciba con los brazos abiertos, ni tampoco opta por reivindicar vehementemente la diferencia de su identidad nacional, refugiándose en una esencia identitaria. Aboga, al contrario, por «fundirme en el anonimato de la pronunciación correcta» (1998:76), es decir, por disolver su identidad en la sonoridad de la lengua francesa y preservar así su «identidad de extranjero» (1998:76). Lo que quiere conservar no es la esencia irrenunciable de una identidad nacional previa, sino una condición del sujeto como eterno extranjero, capaz de pasar por español, por francés o por alemán en una u otra situación, pero consciente de que su verdadera identidad no es ni ser francés, ni español, ni alemán, sino todo ello y nada de eso al mismo tiempo. Adieu, vive clarté... configura literariamente una identidad que transciende las fronteras nacionales y se articula en una ética benjaminiana fundamentada en «la fraternidad de los humillados y ofendidos, la solidaridad de los pobres. De los vencidos» (1998:67). El narrador construye una identidad irónica, múltiple, huidiza, mucho más compleja 
que la marca de cualquier frontera nacional. Toda la obra de Semprún es un reinventar constante de la identidad, un intento de escribir desde nuevas perspectivas, desde una subjetividad que revisita su experiencia y la interpreta desde una perspectiva renovada.

De este modo, su concepción de la identidad se acerca a la que ha desarrollado Claudio Magris en diferentes textos. Para Magris, «la identidad no es un rígido dato inmutable, sino que es fluida, un proceso siempre en marcha, en el que continuamente nos alejamos de nuestros propios orígenes (...); algo que se pierde y se renueva, en un incesante desarraigo y retorno» (1999:74). Y en un aserto que nos hace pensar en Semprún, añade: «Quien mejor ha expresado el amor a la patria (...) ha sido quien ha tenido experiencia del exilio y de la pérdida y ha aprendido, de la nostalgia, que una patria y una identidad no se pueden poseer como se posee una propiedad» (1999:74).

La consciencia irónica de la propia identidad, que no se puede poseer ni instrumentalizar y transciende la mera frontera nacional, es la que demuestra Semprún cuando, al ser repatriado de Buchenwald a Francia, donde es también un extranjero, se da cuenta de que «ya nunca podría regresar a ninguna patria. Ya no había patria para mí. Jamás la habría. O entonces habría varias» (Semprún, 1995:130). Tras la estancia en Buchenwald, se produce un sentimiento de pérdida irrevocable de la identidad y, simultáneamente, nace la consciencia de que la única identidad posible es una identidad irónica y múltiple. Como ha escrito Josep Ramoneda, «la identidad de Semprún es la polivalencia. Sí, la lengua es la patria, pero no una lengua u otra lengua: la lengua como compromiso del intelectual con la palabra. $Y$ ese es el verdadero mensaje cosmopolita» (en Semprún, 2006:10).

Ramoneda habla de cosmopolitismo. Y es que, lo que está en juego en la compleja problematización de la noción de identidad que desarrollan Magris y Semprún, es la consciencia de que ni el sujeto ni su discurso se pueden dejar encerrar en la inmovilidad de una patria esencial y definitiva, que ya está construida, que viene dada previamente y se hace pasar por natural. Su esfuerzo es el de tomar consciencia de las fronteras geográficas, políticas e ideológicas que determinan al sujeto y tratar de superarlas mediante la escritura, articulando un discurso complejo capaz de liberar al individuo del corsé identitario nacional. Como ha explicado Claudio Magris, el gran valor que atesoran lo pequeño y lo local, por ejemplo en el caso de una obra de arte, es precisamente que «resuena en ella una universalidad que transciende aquel apartado 
rincón y forma parte, no en menor medida que una obra ilustre, del gran mundo» (1999:72). Los microcosmos, las culturas pequeñas, tienen sentido cuando somos capaces de detectar la universalidad de la que forman parte, pero en ningún caso cuando exaltamos en ellas el mero localismo: «cultura significa siempre pensar y sentir en grande, tener el sentido de la unidad por encima de las diferencias» (1999:73). Y el humanismo goethiano es, como recuerda Semprún, un modelo de pensamiento que nos permite sustraernos a los esencialismos nacionalistas y al aislacionismo sistemático de lo local. En Goethe «perdura una visión de Europa, y de la nación alemana en Europa, que destaca la necesidad interna del pluralismo y la articulación ideal con el cosmopolitismo universalista» (Semprún, 2006:170).

No obstante, como muy bien ha sabido ver Claudio Magris, la noción de Weltliteratur empieza a aparecer en los textos del viejo Goethe rodeada de una ambivalencia problemática. Goethe no plantea, meramente, la promesa de una futura literatura mundial en la que se establecerá un diálogo desjerarquizado entre todos los pueblos y naciones. El proceso de la Weltliteratur es una realidad mucho más compleja, y Goethe tiene consciencia del papel que él mismo, y cada literatura nacional en concreto, desempeñarán dentro de este proceso. La mundialización de la literatura es un proceso profundamente complejo que, si por un lado es ilusionante, por otro lado aparece como la amenaza de una homogenización acrítica e informe:

\footnotetext{
La actitud de Goethe es (...) ambivalente: se entusiasma con las visiones concretas de un futuro tumultuoso, celebra las nuevas posibilidades que se les ofrecen a los hombres, pero también teme que ese proceso unificador traiga consigo la nivelación y el aplanamiento de lo múltiple y de la vida, una impoética uniformidad, y piensa que esa época de dinámico desarrollo es, en algunos aspectos, una época también tardía y senil, irónica, una edad de epígonos de la poesía (Magris, 1999:138).
}

La Weltliteratur une naciones y culturas, pero también genera una maraña heterogénea y una tensa confrontación de tiempos históricos discontinuos. Este proceso de mundialización pone al descubierto una conflictividad irresoluble y un choque de valores y sensibilidades divergentes. Es por todo ello que «la relación de Goethe con la Weltliteratur está impregnada de esa fascinación-repulsión por la dimensión mundial - desmesurada, genérica y caricaturescaque ha asumido cualquier fenómeno de la historia moderna» (1999:140). Junto a la promesa de 
la democratización y la tentación del cosmopolitismo, la Weltliteratur es causante de equívocos, malentendidos y errores interpretativos. Toda interrogación sobre las condiciones de posibilidad de una internacionalidad literaria deberá tener en cuenta la dimensión doble del proceso weltliterario y los aspectos sombríos que oscurecen sus promesas internacionalistas.

Las telecomunicaciones, las redes sociales, la industria del transporte, la mundialización de la economía en el capitalismo avanzado y, en suma, el estado actual de globalización del mundo, nos ha conducido a un peligroso escenario en el que los juicios de valor parecen haber sido desterrados, y en el que prevalece una líquida homogeneidad que todo lo iguala. La situación social que hizo ver a Goethe que ya no era posible pensar en un desarrollo lineal y unitario de la historia (Magris, 1999:139), que el sujeto se había escindido y había sido arrasado por el progreso, no ha cesado de extremarse más y más hasta nuestros días. Semprún supo leer los interrogantes que planteaba esta situación compleja y problemática:

\footnotetext{
en todos los ámbitos de la cultura y de la política (...) se plantea esta cuestión: ¿cómo mantener, en el caso de que sea necesario, vitalmente necesario, las identidades locales, regionales, nacionales, en un universo cada vez más abierto, y cuyas estructuras tienden de forma objetiva a rebasar las fronteras estatales? (2006:203-204).
}

Semprún detectó la naturaleza contradictoria de un proceso doble, necesario pero paradójico: «simultáneamente al de la integración, hay otro proceso en marcha en Europa. Es el de la explosión de las identidades nacionales, regionales, o locales» (2006:139). La tensión dialéctica entre una supranacionalidad integradora y la reivindicación de las especificidades locales que habían sido reprimidas genera un debate de gran complejidad y en el que resulta muy difícil intervenir intelectualmente, pero cuya urgencia lo convierte en impostergable. Elaborar críticamente una respuesta a la altura de este complejo estado de las cosas es lo que intentó Jorge Semprún, y lo que también hizo y sigue haciendo en nuestros días Claudio Magris, junto con otras figuras, de entre las cuales podemos destacar la de Tzvetan Todorov y sus aportaciones en textos como El miedo a los bárbaros.

\section{Europa amenazada: razón, valores, laicidad}

Todorov ha sabido ver que limitarse a reivindicar los logros alcanzados por la cultura europea, como los ideales de igualdad, libertad y democracia, constituye un ejercicio de 
unilateralidad; al lado de estas conquistas habría que recordar elementos negativos como la esclavitud, el imperialismo o el conservadurismo, que también forman parte del legado europeo. En realidad, en la historia de Europa todo pensamiento ha suscitado su contrario, y ese es quizás el gran valor que atesora: Europa encarna un espíritu crítico, asume que todo se puede discutir y debe ser sometido a examen (Todorov, 2008:247, 248). Es en esta prolijidad de la contradicción y del debate donde el continente europeo se distingue de otras culturas homogéneas y centralistas. Para Semprún, la democracia se define como un proceso inacabable y siempre abierto, que acepta y siente como propios los conflictos y contradicciones y se opone a la unicidad, a la ordenada perfección de los sistemas totalitarios. Aunque reivindica, partiendo de Husserl, que Europa es más una figura espiritual que una unión económica, Semprún es consciente de que no la podemos entender como el fruto de una filosofía depurada o como la materialización de una idea previa, sino que constituye el resultado «denso, a veces opaco y trágico, de largos siglos de enfrentamientos y de amalgamas, de invasiones y de resistencias» (2006:137-8). Europa está más marcada por su lucha contra el totalitarismo que por su filiación al espíritu puro de la filosofía griega, tal como proponía Husserl (1935). Y en todo caso, esta es solo una de las bases de la cultura europea y se encuentra complementada y contrarrestada por otras manifestaciones culturales como la islámica, la ortodoxia cristiana o el judaísmo.

La naturaleza disgregada, compleja y plural de Europa hace muy difícil dar crédito a la existencia de una identidad cultural europea. En cualquier caso, lo que resulta insostenible es considerar que existe una sustancia ontológica que actúa como su núcleo estable. Como ha remarcado Todorov, en Europa las tradiciones locales siguen prevaleciendo sobre la unidad europea, que carece de centro ${ }^{4}$. Entonces, parece que solo podemos hallar su seña de identidad en el sistema de valores que defiende, pero, ¿acaso los valores democráticos e igualitarios que pretende abrazar Europa no tienden a la universalidad? Por lo tanto, la búsqueda de un núcleo identitario europeo resulta más que problemática, y podemos afirmar que la unidad de Europa no reside en una sustancia irradiadora de identidad, sino en una actitud hacia los otros, en su forma de gestionar las identidades regionales que la constituyen, en su respeto a la diversidad y en su ambición de sacar partido de la pluralidad que la constituye.

El problema que plantea este punto de vista es que, si la única característica realmente propia de Europa es su aceptación sistemática de la alteridad, ¿no posee entonces una identidad

\footnotetext{
4 Para Alain Touraine, esta asimetría tiene que ver con la separación entre alta y baja cultura: «Si, cuando la observamos 'desde arriba', es decir desde la perspectiva que ofrecen las obras maestras de la creación literaria, pictórica o musical, Europa aparece como el ámbito de lo universal, cuando la observamos 'desde abajo' se nos presenta como el ámbito de la diversidad» (1990: 19).
} 
extremadamente débil, informe y líquida, que corre el riesgo de disolverse al asumir como propios los postulados ajenos? ¿no se expone al peligro de integrar a través del otro ciertos puntos de vista incompatibles con su propia idea nuclear de respeto de la pluralidad?

Todorov ha planteado esta cuestión paradójica, respondiendo que el cosmopolitismo europeo no asume como propias las diferencias, sino que les proporciona un espacio de coexistencia: «el enfoque cosmopolita no elimina las diferencias, sino que les otorga un marco común y un estatuto de igualdad de derechos» (2008:263). Asimismo, Todorov ha apelado al «principio de laicidad», que garantiza «la buena repartición del espacio público» y asegura «que todo ciudadano dispone además de un ámbito personal que escapa tanto al control del propio estado como al de las religiones» (2008:260).

Sin duda, tanto el diagnóstico como las recetas que Todorov plantea para Europa remiten muy explícitamente a la reflexión sobre la actualidad europea que ha desarrollado Claudio Magris. En ella también desempeñan un papel fundamental los valores, la razón y el concepto de laicidad. Pero el autor triestino es plenamente consciente del signo trágico y problemático inherente a todo intento de repensar Europa desde la responsabilidad, así como también desde la fe en la razón y en los valores del laicismo:

\footnotetext{
No nos podemos sustraer a la responsabilidad de optar por los valores universales y comportarnos en consecuencia; si se renuncia a esta asunción de responsabilidad, en nombre de un relativismo cultural (...) nos hacemos cómplices de la barbarie. Pero hace falta darse cuenta de lo pesada y trágica que es esa responsabilidad y de lo difícil que es resolver esa contradicción» (Magris, 1999:273)
}

A propósito de los valores, Magris ha recurrido a las palabras de San Agustín sobre el tiempo, del cual dijo que sabía perfectamente lo que era mientras no se lo preguntaban, pero que al buscar una definición dejaba de saberlo (1999:285). En otro lugar, preguntado sobre Europa, Magris respondió exactamente con la misma paradoja agustiniana (Cruz, El País, 21/2/10).

Nos encontramos, pues, ante un pensador profundamente preocupado por el devenir de Europa pero que, cuando tiene que definirla, se sabe incapaz de hacerlo. Un pensador convencido de que la respuesta a los problemas de Europa pasa por una recuperación crítica de los valores, pero que sabe que estos no se pueden establecer de forma cerrada e incontestable. Es 
en este sentido que hemos definido la escritura de Magris como conscientemente contradictoria, problemática y sabedora de que el pensamiento se ve siempre desbordado por la complejidad del asunto que trata. La consciencia irónica de la propia falibilidad está en la base de su pensamiento, que se sustenta sobre una concepción del mundo moderno como entrada en crisis de «los fundamentos de nuestro ser que cada vez más nos falta bajo los pies pero que siempre estamos buscando, con irónica pasión y escéptica nostalgia» (1982:136).

Precisamente la contradicción más patente hoy en Europa es la que afecta al mismo tiempo a procesos de unificación agregativa y a movimientos de atomización particularista. La nivelación general reinante y la reivindicación radical de la diversidad «amenazan un fundamento esencial de la civilización europea, la individualidad en su sentido fuerte y clásico, inconfundible en su peculiaridad, pero portadora y expresión de lo universal» (Magris, 1999:10). En la era de la globalización Europa se halla en una encrucijada en la que se ve, pues, doblemente amenazada: por un lado, por la homogeneización niveladora de las identidades; y, por otro lado, por una atomización idólatra y desfiguradora de todo sentido de la unidad. Vivimos un momento único en que, por primera vez en la historia, diferentes civilizaciones y - en consecuencia - diferentes sistemas de valores, cohabitan los unos con los otros y al mismo tiempo se mantienen cerrados en sí mismos. Esta situación despierta la esperanza utopista en la universalización de la vida, pero al mismo tiempo plantea una multiplicidad de interrogantes y problemáticas irresolubles que remiten al desencanto. «Por primera vez en la historia podría surgir una civilización verdaderamente universal. Y sin embargo (...) se dan situaciones en las cuales se encuentran sistemas de valores que no se pueden aceptar el uno al otro» (Magris, en Larrocha, 2007:201).

Sin rehuir nunca las topografías más complejas e incómodas del pensamiento, Magris se propone pensar el otro lado del cosmopolitismo, indagar los peligros que se esconden más allá de las proclamas universalistas encorsetadas y desproblematizadas. Se da cuenta de que es necesario establecer un quantum de universalidad irrenunciable que se debe defender por encima de todo, incluso - en ocasiones - por encima del diálogo mismo, fundamento de toda forma de universalidad. La democracia, que está en la base de la tradición europea, se caracteriza por no alcanzar nunca conclusiones definitivas que ya no acepten ser puestas en duda; pero el dialogismo constante propio de la democracia, la confrontación permanente, 
la asunción de otras perspectivas, deberá detenerse ante ciertas posiciones límite. Es decir: es necesario excluir algunas posturas y puntos de vista que por su propia naturaleza contradicen los principios democráticos del diálogo y la tolerancia de la diversidad. Y una recuperación crítica de los valores será la clave que proteja la pluralidad democrática sin incurrir en un relativismo donde todo está permitido y en el que la idea misma de valor deja de ser operativa.

Ante la homogeneización de la vida social, que amenaza con destruir al individuo o aislarlo en su particularidad, surge la necesidad de un pensamiento fuerte y capaz de establecer jerarquías (Magris, 1999:287), pero que al mismo tiempo sea consciente de su precariedad, pues solo así evitará incurrir en el dogmatismo contra el cual reacciona.

En «Las fronteras del diálogo» (2008), Magris plantea el escenario paradójico de una feria holandesa dedicada a ensalzar la tolerancia. En este lugar, infinidad de mostradores, expositores, tenderetes y pabellones preconizan diversas ideas y formas de ver el mundo en un ambiente de absoluta libertad. Pero Magris se da cuenta de que, en ese espacio caótico y multiforme, en el cual todo vale porque está avalado por una concepción desproblematizada de la tolerancia, podría aparecer cualquier cosa: al lado de los antiracistas, ¿no podrían colocarse los xenófobos?; o al lado de los judíos, los antisemitas; e incluso imagina a un clonado doctor Mengele publicitando la utilidad de sus experimentos con seres humanos. El diálogo y la tolerancia solo pueden mantenerse fieles a su propio concepto si trazan un límite que no pueda ser rebasado. Debido a las transformaciones que ha sufrido nuestro mundo, en el cual las civilizaciones y sus sistemas de valores se desplazan y viven unas junto a las otras, «la tolerancia, o sea el diálogo, y sus contradicciones constituyen un problema universal, que se plantea hoy a la consciencia $-y$ también a la legislación - con una urgencia desconocida hasta ahora en la historia» (Magris, 2006:12).

Si por una parte el diálogo requiere de un sujeto dispuesto a dejarse convencer por el otro, por otra parte es necesario establecer los límites dentro de los cuales se está dispuesto a dialogar, dejando todo lo demás fuera del intercambio dialógico. Europa debe renovar la centralidad de los valores, puesto que solo ellos garantizan la universalidad que constituye la «esencia» europea (2006:14). Ante el peligro de la «indiferencia», mal endémico de nuestras sociedades sobre el que ha llamado la atención Josep Ramoneda (2010) y que postula la intercambiabilidad de todo, debemos retomar críticamente el concepto de valor y excluir del diálogo las posiciones 
que sean inconciliables con un intercambio dialógico en libertad. El objetivo debe ser alcanzar «un justo medio ideal entre un cabal relativismo cultural, respetuoso con las diversidades, y un quantum de universalismo ético necesario sin el cual no es pensable una vida política, civil y moral» (Magris, 2006:21).

Todo intento de pensar Europa en nuestros días debe tratar con urgencia esta paradoja, que ha dado paso a una tensión irresoluble entre el enriquecimiento que puede proporcionar la diversidad cultural y el riesgo de caer en un relativismo en el que todo está permitido. Del mismo modo, Europa tiene la obligación de convertir en europea a la población que llegue de más allá de sus fronteras, pero sin homologarla a la propia identidad, sin privarle de ninguna de sus idiosincrasias nacionales. En la compleja construcción de la universalidad, casi todas las diversidades podrán ser superadas mediante el diálogo, pero surgirán también situaciones en las que será necesario excluir algunas posturas. Y para ello hace falta establecer lo que Magris ha Ilamado «las leyes no escritas de los dioses» (1999:266), aquellas que jamás pueden ser violadas, como el derecho a sepultura que llevó a Antígona a desobedecer el dictado de Creonte.

Pero, ¿cómo estar seguros de que esas «leyes no escritas de los dioses» son realmente principios universales, y no prejuicios raciales, nacionales o de cualquier otro tipo? Nadie está exento de la ceguera, tampoco los hombres de letras o intelectuales, a diferencia de lo que se suele creer. Magris es consciente de la precariedad del pensamiento, de que la identidad no es más que una ficción que Nietzsche se ocupó de desmantelar, de que carecemos de centro estable y de un principio normativo capaz de determinar la validez de los enunciados. Pero nada de eso implica caer en el relativismo y rehuir a la responsabilidad de insistir en la búsqueda de principios universales. Debemos seguir siendo ilustrados, pero «ajenos a toda retórica del progreso, irónicos, humildes, fieles empedernidos de la fe en la razón, en la libertad y la posibilidad de incidir, modestamente desde luego, en el curso del mundo y trabajar por un progreso de la humanidad» (Magris, 2006:27). La consciencia irónica de la propia falibilidad y de la precariedad del pensamiento no es razón suficiente para abandonar la búsqueda; debemos seguir aspirando, melancólicamente, a llegar más allá de la nada que todo lo devora: 
auténtico ilustrado, libre de todo ingenuo triunfalismo, debe saber, para protegerla mejor, lo fácil que es que los vientos de la vida apaguen esa llama (1999:324).

Sin duda, uno de los motivos por los que Magris se mantiene tenazmente fiel a la búsqueda de la razón y de los valores, a pesar de ser consciente de su precariedad, es que escribe desde la memoria de Europa, desde la consciencia de que la historia europea - plagada de guerras, muerte y barbarie- nunca quedará definitivamente atrás. La paz democrática se construye cada día y no puede darse por sentada. El «heroísmo de la razón» (Husserl, 1992:128) al que apelaba Husserl, en 1935, como única forma de salvar a Europa de su propia autodestrucción está latente en la escritura de Claudio Magris, y acompaña - de forma mucho más explícita - todo el proyecto literario de Jorge Semprún. Al igual que Magris, Semprún considera que «la socialdemocracia tiene todavía mucha labor por delante» en su tarea de construir «una Europa plural y unificada en su diversidad, desarrollando a la par instancias supranacionales y reafirmando sus identidades regionales»(Semprún, 2006:109-110). También Semprún observa una situación reinante de desorden, caos y convivencia de diversas culturas y sistemas de valores, y apela a la razón como aquello que nos permitirá no sucumbir a los peligros de esta realidad y aprovechar sus potencialidades: «el desorden actual es plural, policéntrico, creador. Cuando menos, lo es en potencia. A nosotros nos corresponde explotar racionalmente sus virtualidades» (2006:115).

El problema que plantea la razón es que, al mismo tiempo que se cifra como solución al hundimiento de Europa en la barbarie totalitaria, se arraiga en la base de las grandes utopías totalitarias generadas por nuestra historia: los regímenes totalitarios del siglo XX fueron «construcciones de la Europa ilustrada» (Ramoneda, en Semprún, 2006:11). Hace falta, pues, tener muy presentes los límites de la razón, las fronteras que excluyen del diálogo aquellas posiciones que no son aceptables de ningún modo. Semprún, cuya experiencia se forja en los dos grandes totalitarismos del siglo XX e incorpora también el exilio y la vida clandestina en una España sumida en la dictadura, halla el fundamento normativo de la razón en la memoria de la barbarie. Así, define la racionalidad en tanto alteridad del totalitarismo. Pero es consciente, como Magris, de la precariedad de esta razón democrática que jamás alcanza conclusiones estables ni cerradas. La razón jamás cumple su cometido: no existe la sociedad pacificada definitivamente, 
sino que «es preciso comprender que una sociedad civil, democrática, no puede fundamentarse sino en el conflicto, en el juego de las contradicciones» (Semprún, 2006:107).

La razón democrática excluye toda forma de Aufhebung hegeliana y constituye un proceso crítico inagotable. El signo de esa racionalidad siempre sospechosa y en estado de alerta, que prosigue su búsqueda de principios universales pero asume la imposibilidad de alcanzar conclusiones definitivas, nos advierte de que la barbarie nunca se supera definitivamente, nunca se deja atrás, porque la historia no progresa sino que se construye día a día desde el diálogo:

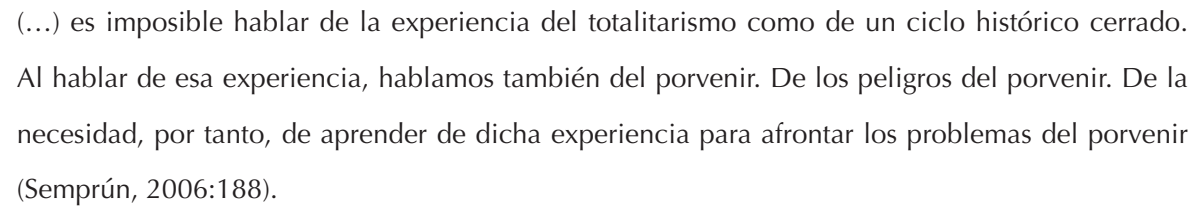

En los textos de Semprún, la experiencia de la barbarie aparece como el fundamento que legitima - y posibilita - la razón. Del mismo modo que Europa es definida negativamente como el resultado de una lucha contra los totalitarismos, la racionalidad necesaria en tanto garante de las democracias europeas se sustenta en un estado de alerta permanente ante la radicalización y la homogeneización del pensamiento, que desemboca inevitablemente en estructuras totalitarias.

Además de en esta misma centralidad otorgada a la memoria de la barbarie, la reivindicación de los valores y de la razón configurada por Magris se estructura en torno a un concepto clave: la laicidad. El pensamiento laico nada tiene que ver con un posicionamiento filosófico respecto a la inexistencia de dios, sino que hace referencia a la capacidad de distinguir entre diferentes competencias y esferas de conocimiento. La laicidad es un «ámbito mental» (Magris, 2006:29) que nos permite distinguir aquello que es demostrable racionalmente de lo que es objeto de fe. La distinción entre lo espiritual y lo público conforma el fundamento éticopolítico de la vida democrática, que debe asentarse sobre unos «principios morales absolutos, no negociables» (2006:45).

La laicidad se traduce en una autoconsciencia del sujeto respecto de sus propias limitaciones, en una desmistificación de todos los ídolos y en una desmitificación de todos los 
mitos. El pensamiento laico se sustrae a todo dogmatismo y al fanatismo monológico. Es tolerante, duda de sus propias certezas y tiene una consciencia irónica de sus carencias. Desde la laicidad, uno puede creer firmemente en unos valores sin olvidar que existen otros, y puede reírse de todo, incluso de sí mismo. Es laico quien asume la responsabilidad de comprometerse con una causa pero no se entrega ciegamente a ella, sino que evita idolatrarla y trata de desacralizarla.

La recuperación crítica de los valores que Magris reivindica como condición de posibilidad de la construcción de una Europa unida en la diversidad se relaciona con la adopción de una consciencia ético-política verdaderamente laica. Y es que el laicismo resguarda a la razón del riesgo de «desnaturalizarse en mera racionalidad calculadora, técnica de poder que no reconoce valores más allá de los hechos, y el peligro de identificarse con una sociedad anónima e impersonal, que nivela y anula esa responsabilidad del juicio individual que es el sostén del laicismo» (1982:342).

Una intrincada dialéctica une a los valores, la razón y la laicidad. Estos conceptos son interdependientes en el pensamiento de Magris, y mantienen una tensión compleja que alcanza también a la noción de individuo. Y es que el individuo ha sido desplazado de la historia y se ha visto relegado a una posición marginal. En las sociedades contemporáneas, las amenazas de la homogeneización y la atomización se ciernen sobre el individuo, sin el cual no es pensable la pervivencia de la racionalidad y ni siquiera la existencia de Europa. En «La bolsa de los valores» (1999) Magris advierte que la raíz cada vez más virtual de la sociedad es el escenario de una mutación del sujeto. El yo ya no es más que «un pulular centrífugo e indistinto», y este hecho «puede comportar desde luego una mayor flexibilidad en el reconocimiento de las libertades ajenas, pero comporta asimismo el riesgo de aguar esa libertad en la indiferencia, de equiparar cada cosa con cualquier otra, en una especie de bazar indiferenciado» (Magris, 1999:288). Solo una recuperación antidogmática de los valores, que permita establecer de nuevo jerarquías, puede salvar al yo de su gelatinosa desindividuación.

Jorge Semprún también señaló la importancia que posee la categoría de individuo en la construcción de una Europa democrática y plural. Es cierto que la historia se ha revelado como un proceso sin fin y sin fines, que «no es el proceso de autorrealización de un astuto y sombrío Espíritu del Mundo» (Semprún, 2006:100). La historia es un proceso acéfalo, sin transcendencia ni dirección fija; no existe ningún concepto absoluto en vías de realización, sino que vivimos 
en la inmanencia histórica. Pero Semprún se apresura a matizar que se trata de una historia «sin objetivos, sí, en efecto. Sin fines últimos y sin fin, también. Pero con sujeto, individuos» (2006:100). En contra de las posturas que postularon, como Louis Althusser, la inexistencia del sujeto (definido como una construcción ficcional de la ideología, que le precede) Semprún remarca la importancia de la individualidad en el marco de los estados democráticos modernos. En Autobiografía de Federico Sánchez (1977) es donde Semprún llevó a cabo una crítica más extensa y completa de la postura althusseriana (cfr. por ejemplo 1977:26-17 y 75). Su desengaño respecto a la utopía comunista conduce a Semprún a un distanciamiento crítico de la dialéctica marxista y a recuperar desde el humanismo la noción de sujeto/individuo. Su debate con Althusser recogido en la Polémica sobre marxismo y humanismo (1968) atestigua nítidamente esta evolución crítica.

Magris y Semprún comparten un mismo esfuerzo intelectual por preservar la individualidad ante la homogeneización de las sociedades contemporáneas. Asimismo, se enfrascan en una búsqueda de los valores que puedan salvar a Europa de incurrir en un relativismo ético en el que todo esté permitido, y tratan de sentar las bases que posibiliten una recuperación de la razón democrática, pues constituye el gran baluarte del pensamiento europeo.

Pero ambos son conscientes de que este itinerario crítico es penoso y precario, de que vivimos en la inmanencia histórica y nos hallamos ante la imposibilidad de encontrar un gran relato normativo capaz de dar sentido a nuestra existencia y de legitimar los valores y la razón. El pensamiento ya no puede aspirar al sistematismo y debe asumir que su naturaleza es paradójica y contradictoria. La utopía nos obliga a proseguir incansablemente la búsqueda, pero el desencanto nos recuerda irónicamente la precariedad del camino.

\section{Conclusiones. El imperativo de seguir pensando Europa}

A Claudio Magris y Jorge Semprún les une, por encima de todo, su común preocupación por Europa, la cual incorpora un balance crítico del pasado europeo, la pregunta por su actualidad y la inquietud ante su futuro. Semprún y Magris asumen críticamente la necesidad de pensar la cultura europea como un todo que transciende los Estados-nación de los que surgen las ideas, pero al mismo tiempo son conscientes de que cada idea ha nacido de una historicidad y de un contexto ideológico y cultural específico que no se puede dejar de lado. 
Las fronteras (geográficas, políticas, simbólicas) existen, e incluso son necesarias porque sin ellas no sería posible la identidad individual; no podemos ignorarlas apelando a un cosmopolitismo desproblematizado que no se corresponde con la complejidad geopolítica y cultural de Europa, pero tampoco podemos dejarnos encerrar por ellas.

En todas estas consideraciones, Magris y Semprún demuestran su filiación a la idea de Weltliteratur que Goethe acuñó en los últimos años de su vida con el fin de intervenir en el devenir de Europa. Repiensan críticamente el problema de la Weltliteratur y tratan de resarcirla de su maltrato y de su utilización problemática por parte de la historia de la literatura comparada. De este modo, los planteamientos de Semprún y de Magris dialogan con la Weltliteratur goethiana, que en unas ocasiones aparece de forma explícita, y en otras es simplemente un referente inexcusable en diálogo con el cual desarrollar una obra literaria que aspira a ser, ante todo, europea. Es incontestable la voluntad weltliteraria, transfonteriza, de sus textos, que en ningún caso aspiran a una universalidad utópica, pero en todo momento tratan de articular problemáticamente el problema de las fronteras nacionales y se proyectan sobre el fondo de la totalidad de Europa entendida como unidad en la diversidad.

Sin embargo, tanto uno como otro son conscientes de que la construcción de una identidad europea es profundamente problemática, compleja y contradictoria. La historia de Europa está repleta de retrocesos, embustes y fracasos que debemos tomar en consideración. En este sentido, el hundimiento del continente europeo en la barbarie de los totalitarismos en el siglo XX nos obliga a renunciar a toda inocencia y a contemplar Europa desde la consciencia de que su trágico pasado jamás se rebasa definitivamente, sino que es necesario un pensamiento crítico que renueve sus propios presupuestos día a día y sea consciente de que la racionalidad democrática es un proceso constante que no tiene fin.

Europa se ve hoy amenazada por un doble proceso: por un lado, la homogeneización gelatinosa de las diferencias; y por otro lado, por la reivindicación esencialista exacerbada de esas mismas diferencias. Como ha mostrado Magris en El Danubio o en Microcosmos, un lugar concreto puede contener la totalidad europea de la que forma parte. Así pues, debemos insistir en la dialéctica que se establece entre lo particular y lo universal, que se remiten recíprocamente lo uno a lo otro, en el marco de la cultura europea (que, potencialmente, no es solo europea). 
Sin embargo, existe una amenaza ante la que debemos estar atentos. La han señalado Magris, Semprún, Todorov o Judt, y se trata del riesgo de que el paso del tiempo lleve a Europa a olvidar su pasado, a olvidar los totalitarismos en oposición a los cuales se configura el proyecto europeo. Aunque Todorov (2008:18-19) y Magris (2002) han señalado que ningún proyecto, incluido el europeo, puede construirse como simple oposición a un enemigo común, lo que tampoco es posible es olvidar la carga complejísima y muy problemática de la historia europea. «En la actualidad Europa ya no tiene enemigos a su altura (...) De repente la construcción europea se estanca» (Todorov, 2008:267).

Actualmente Europa parece haber perdido su centralidad política y a menudo se observa con completo escepticismo y desilusión. Muchas voces dan ya por fallido el proyecto europeo, que se habría revelado como una simple organización económica que ha perdido de vista todo sentido de la unidad cultural, política, ética y democrática. Los acontecimientos que han sucedido en los últimos tiempos parecen apuntar a la demolición definitiva de cualquier ideal europeísta. No se trata solo del abandono de la Unión Europea por parte de Gran Bretaña, sino que además se ha producido un avance sin precedentes de la extrema derecha en países como Grecia, Dinamarca, Austria, Alemania, Polonia o Hungría. Tras la victoria del UKIP, son muchos los partidos que desde diversos estados europeos proclaman la necesidad de abandonar la Unión Europea y restituir un concepto aislacionista y cerrado de las fronteras nacionales. Además, la incapacidad de los políticos europeos de configurar una respuesta política a la tragedia de los refugiados ha supuesto una puesta en abismo casi definitiva del significado, la validez y la utilidad de la idea de Europa.

A la luz de estos últimos procesos, ¿no resulta urgente recuperar la advertencia que lanzan Semprún y Magris sobre la necesidad de preservar la utopía europea como un artefacto ético, refrendado por la memoria, capaz de evitar que regrese la barbarie? Si algo nos enseñan las reflexiones en torno a Europa de Jorge Semprún y Claudio Magris, es a no dar nunca por sentado que sepamos qué es Europa, a no dar nunca por sentada la pacificación del continente europeo, ni su misma existencia, ni la imposibilidad del renacimiento de la barbarie. Nos enseñan a estar atentos, a ser críticos y suspicaces y a comprender la eterna debilidad del proyecto europeo, construido sobre la delicada paradoja de la unidad en la diversidad. Ante los últimos acontecimientos de la política europea, ¿no deviene un imperativo retomar sus textos, 
y comprender junto a ellos que la historia no ha acabado, que no acabará nunca? ¿No resulta inexcusable reflexionar sobre la vecindad siempre renovada de la barbarie, y recordar que la razón democrática jamás cumple definitivamente su cometido? ¿¿No nos recuerdan que Europa está siempre construyéndose y pensándose, pero que no se termina de construir ni se termina de pensar nunca?

\section{Bibliografía}

ALTHUSSER, Louis, SEMPRÚN, Jorge, SIMON, Michel y VERRET, Michel: Polémica sobre marxismo y humanismo, México DF: Siglo XXI, 1968.

AUGSTEIN, Franziska: Lealtad y traición. Jorge Semprún y su siglo. Barcelona: Tusquets, 2010.

CERVANTES, Miguel: Don Quijote de la Mancha. Edición de Francisco Rico, Barcelona: Crítica, 2001.

CÉSPEDES GALLEGO, Jaime: La obra de Jorge Semprún. Claves de interpretación. Vol I: autobiografía y novela. Berna: Peter Lang, 2005.

CRUZ, Juan: «Sueño con un estado federal europeo», entrevista con Claudio Magris en El País, $21 / 2 / 2010$.

FONTANA, Josep: «Europa: història i identitat», en L'Espill, Universitat de València i Edicions Tres i Quatre, 2005, n² 20, 2005.

FOX MAURA, Soledad: Ida y vuelta: la vida de Jorge Semprún. Barcelona: Debate, 2016.

FUMAROLI, Marc; BONNEFOY, Yves; WEINRIC, Harald, ZINK; Michel (eds.): Identité litteéraire de l'Europe. Paris: Presses Universitaires de France, 2000.

GARCÍA DÍAZ, Ana: «El espíritu de la resistencia como articulador del proyecto político de la UE. Un análisis de 'La escritura o la vida' de Jorge Semprún», en $452^{\circ}$ F. Revista electrónica de teoría de la literatura y literatura comparada, 5, 2011, pp. 45-62.

HUSSERL, Edmund: Invitación a la fenomenología. Bellaterra: Paidós, 1992. 
JOAN I TOUS, Pere: ««ll faut beacoup d'artifice pour faire passer une parcelle de vérité». La poética del fracas en la literature concentracionaria de Jorge Semprún», en Sánchez y Spiller (eds): Poéticas del fracaso. Günter Narr: Tübingen, 2009.

JUDT, Tony: ¿Una gran ilusión? Un ensayo sobre Europa. Madrid: Santillana, 2013.

LARROCHA, Eduardo: «Claudio Magris: «Cada generación debe redefinir la utopía»», entrevista en Turia: revista cultural, Instituto de Estudio Turolenses de la Diputación Provincial de Teruel, no 80, 2006-7, pp. 283-295.

MAGRIS, Claudio (1982) Ítaca y más allá. Huerga y Fierro editores, Madrid, 1998.

--------(1999) Utopía y desencanto. Anagrama, Barcelona, 2001.

---(2002) «Abbiamo bisogno d'un nemico comune?», en Nohelicon, XXIX, 2002.

---(2006) La historia no ha terminado. Anagrama, Barcelona, 2008.

MONTAIGNE, Michel: Ensayos. Seguidos de todas sus cartas conocidas hasta el día. 2 vols. Buenos Aires: Aguilar, 1961.

MORIN, Edgar: Pensar Europa. Barcelona: Gedisa, 1998.

NIETZSCHE, Friedrich: La gaya ciencia. Madrid: Poesía y prosa popular, 1987.

RAMONEDA, Josep «Una identitat contra la guerra civil», en L'Espill, Universitat de València i Edicions Tres i Quatre, 2005, nº 20.

---------Contra la indiferencia. Barcelona: Galaxia Gutenberg, 2010.

RIDAO, José María: «Claudio Magris y la Europa desvanecida», en Turia: revista cultural, Instituto de Estudio Turolenses de la Diputación Provincial de Teruel, nº 80, 2006-7, pp. 199204.

SAID, Edward: El mundo, el texto y el crítico. Barcelona: Random House Mondadori, 2008.

SEMPRÚN, Jorge (1977) Autobiografía de Federico Sánchez, Planeta, Barcelona.

---------(1980) Aquel domingo, Tusquets, Barcelona, 2011.

--(1995) La escritura o la vida, Tusquets, Barcelona.

--(1998) Adiós, luz de veranos, Tusquets, Barcelona.

--(2001) Viviré con su nombre, morirá con el mío. Tusquets, Barcelona, 2011.

--(2006) Pensar en Europa. Tusquets, Barcelona, 2011.

SEMPRÚN, Jorge y VILLEPIN, Dominique: El hombre europeo. Madrid: Espasa Calpe, 2006. 
SZÁVAI, János (dir.): Problématique de la littérature européene. Cahiers de la nouvelle Europe, 4/2005. L'Harmattan, Paris.

TODOROV, Tzvetan: El miedo a los bárbaros. Barcelona: Círculo de lectores, 2008.

TOURAINE, Alain: «¿Existe realmente una cultura europea?», en CASADO, Josefina y AGUDÍEZ, Pinar (comp): El sujeto europeo. Editorial Pablo Iglesias, Madrid, 1990. 